\title{
Age of regrowth of irrigated Digitaria decumbens pastures, season of kidding, milk production and growth rate of Creole goats in Guadeloupe (FWI) ${ }^{1,2}$
}

\author{
Gisèle Alexandre ${ }^{3, *}$, Gilles Aumont ${ }^{4}$, Ode Coppry ${ }^{5}$, \\ Jérome Fleury ${ }^{5}$ and Hary Archimède $e^{3}$
}

J. Agric. Univ. P.R. 91(3-4):169-182 (2007)

\begin{abstract}
The effect of age of regrowth (AR) of pasture herbage on milk production of Creole goats and growth rate of their kids while grazing irrigated Digitaria decumbens pastures was studied in Guadeloupe. Eighty-four does were used in an experiment to compare two rotational grazing systems over a one-year period during three kidding seasons classified as rainy, dry and intermediate. System AR21 allowed seven days of grazing and 21 days of regrowth whereas system AR35 allowed seven days and 35 days, respectively. An annual average stocking rate of $1,800 \mathrm{~kg}$ live-weight /ha was maintained in both systems. Dry matter (DM) yields were higher $(P<0.01)$ in the AR35 than in the AR21 system over the three seasons (4,935 vs. $2,948 \mathrm{~kg} / \mathrm{ha}$ ). Total biomass in the paddocks at the start of each grazing cycle varied between 11 and $19 \mathrm{DM} \mathrm{kg} / \mathrm{animal}$, depending significantly $(P<0.01)$ on the season. Age of regrowth had no effect. Daily milk production (938 to $1,033 \mathrm{~g}$ ) also varied with the season but did not differ according to AR. Average daily gain (ADG) of kids in the AR21 system was lower by $23 \%$ than that of kids under the AR35. These differences were greater when ADG was adjusted for birth weight and milk production of the dam. Results may have been complicated by differences in gastro-intestinal parasitism, but this experiment showed that lowering AR of Digitaria decumbens pastures managed under intensive conditions did not significantly improve animal performance.
\end{abstract}

Key words: Digitaria decumbens, age of regrowth, Creole goats, milk production, growth of kids, kidding season

${ }^{1}$ Manuscript submitted to Editorial Board 10 October 2006.

${ }^{2}$ We gratefully acknowledge the support of R. Arquet, P. Mulciba and A. Nepos, during the field work. This study has been supported by the "Region Guadeloupe" and the "European Community" (FEOGA).

${ }^{3}$ INRA UR 143, Unité de Recherches Zootechniques, Domaine Duclos, 97170 PetitBourg, Guadeloupe, French West Indies. *Author to whom correspondence should be addressed; e-mail: Gisele.Alexandre@antilles.inra.fr

${ }^{4}$ INRA UAR 564, Animal Health Department, 37380 Nouzilly, France.

${ }^{5}$ INRA UE 467, Gardel, 97160 Le Moule, Guadeloupe, French West Indies. 


\section{RESUMEN}

Periodo de re-establecimiento de pasturas irrigadas de Digitaria decumbens, época de nacimiento, y la producción de leche y tasa de crecimiento de cabras Creole en Guadalupe

Se estudió el efecto del periodo de re-establecimiento (PR) de pasturas sobre la producción de leche de cabras Creole y la tasa de crecimiento de sus cabritos mientras pastaban en pasturas irrigadas de Digitaria decumbens en la isla de Guadalupe. Se usaron 84 cabras en un experimento para comparar dos sistemas rotacionales de pastoreo por un periodo de un año. El sistema PR21 permitía siete días de pastoreo y 21 días de re-establecimiento del pasto, mientras el sistema PR 35 permitía siete días de pastoreo y 35 días de re-establecimiento. Se compararon los dos sistemas durante tres estaciones de nacimiento de cabritas; estaciones clasificadas como lluviosa, seca o intermedia. En ambos sistemas se mantuvo una carga animal promedio de $1,800 \mathrm{~kg}$ de peso vivo /ha/año. La producción de materia seca (MS) fue mayor ( $P<0.01$ ) en el PR 35 que en el PR 21 en las tres estaciones, con 4,935 vs. $2,948 \mathrm{~kg} / \mathrm{ha}$, respectivamente. La biomasa total en los pastos al comienzo de cada ciclo de pastoreo variaba entre 11 y $19 \mathrm{~kg} \mathrm{MS/}$ animal, según la estación. El periodo de re-establecimiento no tuvo ningún efecto. La producción de leche (938 a $1,033 \mathrm{~g}$ leche/día/cabra) varió con la estación pero no con la edad de re-establecimiento. La ganancia diaria promedio en peso de los cabritos del sistema PR 21 fue $23 \%$ menor que la de los cabritos en PR 35. Estas diferencias fueron aún mayores cuando la ganancia diaria promedio en peso se ajustó al peso al nacimiento y a la producción de leche de la cabra. Los resultados se pueden haber afectado por la presencia de parásitos gastrointestinales; sin embargo, este experimento demuestra que disminuyendo el periodo de re-establecimiento de Digitaria decumbens manejada intensivamente no se mejora significativamente el desempeño de los animales.

Palabras clave: Cabras Creole, Digitaria decumbens, producción de leche, periodo de re-establecimiento, época de nacimiento

\section{INTRODUCTION}

In the West Indies, suckling goats and their offspring are raised mainly under extensive systems of production. The most widespread feeding mode is grazing (Devendra and Burns, 1983; Alexandre et al., 1997) and mainly on natural pastures. Performance of animals raised under these conditions is low. More intensive utilization of forages is one way of increasing the production of small ruminants in tropical areas. For the past 20 years in Guadeloupe, increased productivity has been associated with an improvement in reproductive traits and intensive management of the local breed, i.e., Creole goat (Alexandre et al., 1999). Typically, does of about $33 \mathrm{~kg}$ live-weight (LW) now have high reproductive capacity and annually produce weaned offspring with a combined LW of up to $20 \mathrm{~kg}$ (i.e., two-thirds of the doe's LW). The conventional feeding system under investigation in this study is based on a 35-day system of rotation using Digitaria decumbens. This species is considered to be well suited to our conditions in terms of productivity, chemical composition and mineral content (Aumont et al., 1995; 
Aumont et al., 1996). Tropical pastures $\left(\mathrm{C}_{4}\right.$ grasses $)$ are productive but their rapid maturation leads to a high level of lignification (Minson, 1990; Humphreys, 1991). Tropical forage, even when fertilized and irrigated, is of moderate nutritive value $[0.55$ dry matter (DM) digestibility and $95 \mathrm{~g}$ crude protein (CP)/ $\mathrm{kg} \mathrm{DM}$ ] (Minson, 1990; Aumont et al., 1995), all of which is a major limiting factor in animal production. It is therefore necessary to optimize the use of grazed forages and to develop management approaches to achieve high-quality grazing.

Intake and digestibility were shown to be high during the first month of forage regrowth (Aumont et al., 1995; Archimède et al., 2000) and adequate for feeding housed animals. Moreover, studies conducted on cut grass by Cruz et al. (1989) indicated that the canopy structure of Pangola grass might be optimal at 21-day regrowth. On the assumption that favorable modifications in forage availability and sward structure improve the intake level of grazing ruminants (Minson, 1990; Humphreys, 1991; Baumont et al., 2000), the objective of this experiment was to study the effect of age of regrowth (AR) of Pangola grass on both sward characteristics and animal performances (milk production of suckling does and growth rate of their kids).

\section{MATERIALS AND METHODS}

This study was carried out at the Animal Production Unit of the INRA Research Centre in Guadeloupe, a humid tropical island in the Caribbean $\left(16^{\circ} 1^{\prime} \mathrm{N}, 61^{\circ} 6^{\prime} \mathrm{W}\right)$. The experimental farm in question is located in the driest area of the island, where annual rainfall averages $1,280 \mathrm{~mm}$, with a dry season lasting from January to May during which time precipitation is less than $70 \mathrm{~mm}$ per month. Maximum air temperature varies from $27^{\circ} \mathrm{C}$ (January) to $32^{\circ} \mathrm{C}$ (August) and minimum from 21 to $25^{\circ} \mathrm{C}$. Relative humidity is usually above $70 \%$ and length of daylight ranges from 11 to $13 \mathrm{~h}$.

Two methods of pasture management were tested: in the first, pastures were grazed rotationally on a 21-day regrowth cycle all year round (AR 21); this was compared to the control system, in which pastures were grazed on the basis of a 35-day regrowth cycle (AR 35). Two plots of pasture dominated by Digitaria decumbens were employed. Each plot was grazed by 14 multiparous suckling Creole goats rearing twins. The first plot of $2,768 \mathrm{~m}^{2}$ was equally divided into four paddocks (AR21; with seven days of grazing in each paddock, allowing a regrowth period of 21 days). The second plot of grazing of 2,658 $\mathrm{m}^{2}$ was divided equally into six paddocks (AR35, also with seven days of grazing in each paddock and allowing a regrowth period of 35 days). The paddocks 
of both AR plots were irrigated and fertilized with $300 \mathrm{~kg} / \mathrm{ha}$ nitrogen. At the end of each grazing period a 30-12-18 N-P-K fertilizer was applied. The experiment lasted for one year, and the two ARs were compared over three kidding seasons.

Eighty-four adult female Creole goats with a mean LW of $31.5 \pm 5.4$ $\mathrm{kg}$ were used in the experiment. The animals were managed so as to obtain three parturitions within a two-year mating system. The male effect was systematically used for ensuring ovulatory and oestrus functions. The birth periods occurred during the dry season (DS), mid-January to mid-February; the intermediate season (IS), mid-May to mid-June; and the rainy season (RS), mid-September to mid-October. For each season, there were two AR groups, each consisting of 14 multiparous goats (lactation number ranging between three and five) suckling twins. Each doe was supplemented daily with $200 \mathrm{~g}$ of pellet feed of $87 \%$ DM. The supplement was composed of $70 \%$ maize, $20 \%$ soya bean cakes and $10 \%$ fish meal (11.9 MJ metabolizable energy and $190 \mathrm{CP}$ g/kg DM). Prophylactic treatments were applied against ticks (acaricide spray application every two weeks) and internal parasites (anthelminthic drenchings every month for the suckling kids and every 1.5 months for adults). Kids were weaned between 10 and 12 weeks of age.

Biomass and morphological composition of the herbage were determined at the start and at the end of the grazing period at least twice during each season of production. Herbage mass was estimated by cutting a $0.09-\mathrm{m}^{2}$ area with hand-held electric clippers at 10 different places in the paddock. Samples were weighed while still fresh and two sub-samples of $300 \mathrm{~g}$ were taken to determine DM content (drying to constant weight at $60^{\circ} \mathrm{C}$ in a forced draft oven for $48 \mathrm{~h}$ ), and morphological composition. The latter was determined by manually sorting leaves, stems and debris (including senescing and dead materials) prior to drying. The same procedure was used when the animals exited the paddock. Table 1 gives the chemical composition of the forage offered. Daily herbage production was defined as total biomass (determined before grazing) divided by the number of days of regrowth. The daily forage availability per doe was calculated as the biomass multiplied by the surface area of the paddock and divided by 14 (does) and by seven (days of grazing per paddock).

Milk production was estimated weekly from birth of kids to weaning by using the oxytocin method adapted to suckling Creole goats by Alexandre (1983). Oxytocin was administered twice at the rate of 5 I.U. by intravenous injection. A 4-h interval was observed and animals were then milked by hand. The first milking was done to empty the udder and at the second milking, four hours later, the weight of the milk produced was recorded. A body condition score (BCS), assessed by two 
TABLE 1.-Chemical composition of Digitaria decumbens pasture herbage grazed by the suckling does according to age of regrowth (AR) of the forage (defined in the text) (Aumont et al., 1991; Aumont et al., 1996).

\begin{tabular}{|c|c|c|}
\hline Variable (g/kgDM) & AR 21 days & AR 35 days \\
\hline Total crude protein & 135 & 123 \\
\hline Metabolizable energy (MJ/kg DM) & 10.8 & 9.05 \\
\hline NDF & 729 & 701 \\
\hline $\mathrm{ADF}$ & 423 & 391 \\
\hline $\mathrm{Ca}$ & & \\
\hline $\mathrm{P}$ & & \\
\hline $\mathrm{Mg}$ & & \\
\hline $\mathrm{Na}$ & & \\
\hline $\mathrm{K}$ & & \\
\hline
\end{tabular}

NDF: neutral detergent fibre; ADF: acid detergent fibre.

Ca: calcium; P: phosphorus; Mg: magnesium; Na: sodium; K: potassium; not determined according to age of regrowth

scorers on the same day, was determined for each female according to the method described by Aumont et al. (1994), which involves 5 BCS levels and has $88 \%$ repeatability and $80 \%$ reproducibility. The kids were weighed at birth, then once per week. Does were also weighed weekly.

Herbage data were analyzed by using the SAS (1989) general linear model. The model contained effects due to age of regrowth (AR21 and AR35), season (DS, IS and RS) and age of regrowth $x$ season interaction. Model 1 was as follows:

$\mathrm{Y}_{\mathrm{ij}}=\mathrm{m}+\mathrm{AR}_{\mathrm{i}}+\mathrm{S}_{\mathrm{j}}+(\mathrm{ARS})_{\mathrm{ij}}+\mathrm{e}_{\mathrm{ij}}$

Where $\mathrm{m}$ is the overall mean;

$\mathrm{AR}_{\mathrm{i}}$ is the age of regrowth effect $(\mathrm{i}=1,2)$;

$\mathrm{S}_{\mathrm{j}}$ is the season effect $(\mathrm{j}=1,2,3)$;

$\mathrm{ARS}_{\mathrm{ij}}$ is the age of regrowth * birth season interaction, and

$\mathrm{e}_{\mathrm{ij}}$ is the residual term.

The BCS and LW of does were analyzed both according to model 1, and also including the does' lactation number (model 2). Moreover, milk production (MP) was analyzed according to model 2 with BCS and LW of does included. The kids' LW and average daily gain (ADG) at a fixed age were analyzed according to model 1 with addition of the sex and birth weight of the kid and the maternal MP. There were 14 does and 28 kids per treatment combination.

\section{RESULTS}

The average annual stocking rates for the two grazing systems during the different seasons varied from 1,600 to $2,000 \mathrm{~kg}$ LW/ha 
throughout the suckling period. All supplemental feed offered was consumed. Herbage biomass varied between 2,380 and $6,195 \mathrm{~kg} \mathrm{DM} / \mathrm{ha}$, among different $\mathrm{AR}$ and season combinations (Table 2); the effects of $\mathrm{AR}(\mathrm{P}<0.001)$ and season $(\mathrm{P}<0.01)$ were significant. There was no difference in daily herbage production (common mean $141 \mathrm{DM} \mathrm{kg} / \mathrm{ha}$ ) between the two ARs, but it was significantly lower during the DS than in the IS (108 vs. $172 \mathrm{DM} \mathrm{kg} / \mathrm{ha}, \mathrm{P}<0.01$ ). The values recorded for leaves, dead material and stem proportions were 38,10 and $52 \%$ for AR35 vs. 36, 9 and $54 \%$ for AR21, but these differences reached significance $(\mathrm{P}<0.05)$ only for stem proportion. There was a significant AR by season interaction in the morphological composition of the forage. The percentages of leaf and dead material were higher, but those of stems were lower $(P<0.05)$ in the control system (AR35) than in the AR21 plots during the DS (Table 2), whereas during the IS no difference was observed between the two ARs.

The leaf to stem ratio averaged 0.70 and was always lower than unity (Table 2). Values were higher in AR35 pasture than in AR21 during DS and RS but not in IS, and averaged 0.76 vs. 0.64 overall $(\mathrm{P}<$ 0.05 ), respectively. No seasonal effect on this characteristic was observed for the AR21 forage whereas it was significant in AR35 plots; ratio was lower during the IS than during the other two seasons (about $20 \%$ difference).

Forage availability in the paddocks when grazing started ranged between 11 and $19 \mathrm{DM} \mathrm{kg}$ /doe depending on the AR system and the season. No difference between AR was determined; however, a seasonal effect $(\mathrm{P}<0.01)$ was observed with 11,15 and $18 \mathrm{DM} \mathrm{kg} / \mathrm{doe}$ for the DS, RS and IS, respectively. At all AR and seasons, large amounts of residual forage were observed (up to $61 \%$ of the total green material, i.e., leaves + stems) at the end of each grazing cycle (Figure 1 ). Average refusals were $27 \%$ for leaves vs. $81 \%$ for stems.

The average daily milk production over the suckling period, adjusted for BCS and LW, ranged between 880 and 1,060 g (Table 3). There was no significant effect of AR or of season on milk production, but a significant interaction between these two factors $(P<0.05)$ was found. During the first month of lactation, goats in the AR21 group produced $19 \%$ less milk in the dry than in the other two seasons. During the second month of lactation the females in the AR35 group produced $20 \%$ more in the intermediate season. The mean BCS decreased from 2.5 to 2.1 from the beginning to the end of lactation. No significant effects of age of regrowth or of season were observed.

The mean birth weight of the kids was $1.75 \mathrm{~kg}$. Pre-weaning average daily gains of kids, adjusted for birthweight and the dam's MP (Table 3), were significantly lower $(\mathrm{P}<0.01)$ in the AR21 $(73 \mathrm{~g})$ than in 
TABLE 2.-Sward characteristics in rotational pasture systems based on irrigated Digitaria decumbens grazed by suckling Creole goats in Guadeloupe (F.W.I.), according to age of regrowth and to season.

\begin{tabular}{|c|c|c|c|c|c|c|c|c|c|c|c|c|c|c|}
\hline \multirow[b]{2}{*}{ Variable } & \multicolumn{4}{|c|}{21 days } & \multicolumn{4}{|c|}{35 days } & \multicolumn{3}{|c|}{ Season } & \multicolumn{3}{|c|}{ Level of significance $^{1}$} \\
\hline & $\mathrm{DS}^{2}$ & $\mathrm{IS}^{2}$ & $\mathrm{RS}^{2}$ & Mean & $\mathrm{DS}$ & IS & RS & Mean & DS & IS & RS & $\mathrm{AR}^{3}$ & $\mathrm{~S}^{3}$ & $\mathrm{AR}^{*} \mathrm{~S}^{3}$ \\
\hline Herbage mass (kg DM/ha) & 2,380 & 3,504 & 2,961 & 2,948 & 3,570 & 6,195 & 5,040 & 4,935 & 4,000 & 2,975 & 4,849 & $* * * *$ & $* *$ & * \\
\hline $\begin{array}{l}\text { Daily herbage production } \\
\text { (DM kg/ha/day of regrowth) }\end{array}$ & 113 & 167 & 141 & 140 & 102 & 177 & 144 & 141 & 108 & 172 & 142 & NS & *** & NS \\
\hline Leaf proportion $(\%)$ & 36.00 & 35.60 & 35.10 & 35.90 & 41.50 & 35.50 & 38.70 & 38.50 & 38.70 & 35.50 & 36.90 & NS & NS & $*$ \\
\hline Stem proportion (\%) & 57.00 & 52.50 & 55.90 & 54.90 & 49.00 & 52.70 & 50.50 & 51.80 & 53.00 & 52.60 & 53.20 & * & NS & $*$ \\
\hline Dead material $(\%)$ & 7.00 & 11.90 & 9.00 & 9.40 & 9.50 & 11.80 & 10.80 & 10.50 & 8.50 & 11.20 & 9.90 & NS & NS & * \\
\hline Leaf/stem ratio & 0.63 & 0.68 & 0.63 & 0.64 & 0.84 & 0.67 & 0.77 & 0.76 & 0.69 & 0.74 & 0.67 & $*$ & $*$ & $*$ \\
\hline $\begin{array}{l}\text { Weekly forage availability } \\
\text { (DM kg /doe) }\end{array}$ & 11.80 & 17.30 & 14.60 & 14.60 & 11.30 & 19.60 & 15.90 & 15.60 & 11.50 & 18.40 & 15.30 & NS & $* * *$ & $*$ \\
\hline
\end{tabular}

${ }^{1 *} \mathrm{P}<0.05,{ }^{* * *} \mathrm{P}<0.01,{ }^{* * * *} \mathrm{P}<0.001, \mathrm{NS}$ : non significant effect $(\mathrm{P}>0.05)$.

2DS: Dry season, IS: Intermediate season, RS: Rainy season.

${ }^{3}$ Effect of age of regrowth (AR), season (S) or interaction $\mathrm{AR}^{*} \mathrm{~S}$. 
TABLE 3.-Milk production of Creole goats and growth performance of their offspring in rotational grazing systems based on irrigated Digitaria decumbens in Guadeloupe (F.W.I.), according to age of regrowth and season.

\begin{tabular}{|c|c|c|c|c|c|c|c|c|c|c|c|c|c|c|}
\hline \multirow[b]{2}{*}{ Variable } & \multicolumn{4}{|c|}{21 days } & \multicolumn{4}{|c|}{35 days } & \multicolumn{3}{|c|}{ Season } & \multicolumn{3}{|c|}{ Level of significance ${ }^{1}$} \\
\hline & $\mathrm{DS}^{2}$ & $\mathrm{IS}^{2}$ & $\mathrm{RS}^{2}$ & Mean & DS & IS & RS & Mean & DS & IS & RS & $\mathrm{AR}^{3}$ & $\mathrm{~S}^{3}$ & $\mathrm{AR}^{*} \mathrm{~S}^{3}$ \\
\hline & \multicolumn{14}{|c|}{ Milk production (g/day) } \\
\hline Overall production ${ }^{4}$ & 878 & 1,007 & 945 & 943 & 998 & 1,059 & 1,026 & 1,028 & 938 & 1,033 & 985 & NS & NS & $*$ \\
\hline $10 \mathrm{~d}-30 \mathrm{~d}^{5}$ production & 934 & 1,113 & 1,028 & 1,025 & 1,042 & 1,157 & 1,098 & 1,099 & 988 & 1,135 & 1,063 & NS & NS & * \\
\hline \multirow[t]{2}{*}{$30 \mathrm{~d}-70 \mathrm{~d}$ production } & 820 & 901 & 864 & 862 & 909 & 962 & 936 & 936 & 864 & 931 & 900 & NS & NS & * \\
\hline & \multicolumn{14}{|c|}{ Growth performance } \\
\hline Birth weight (kg) & 1.7 & 1.8 & 1.8 & 1.74 & 1.6 & 1.8 & 1.7 & 1.73 & 1.67 & 1.83 & 1.74 & NS & NS & NS \\
\hline $\mathrm{ADG}^{6} 0 \mathrm{~d}-70 \mathrm{~d}(\mathrm{~g})$ & 75 & 76 & 75 & 75 & 81 & 86 & 83 & 83 & 78 & 81 & 79 & $* *$ & NS & $*$ \\
\hline ADG $10 \mathrm{~d}-30 \mathrm{~d}(\mathrm{~g})$ & 72 & 73 & 73 & 73 & 80 & 87 & 82 & 86 & 80 & 80 & 77 & $* *$ & NS & * \\
\hline ADG $30 \mathrm{~d}-70 \mathrm{~d}(\mathrm{~g})$ & 71 & 75 & 73 & 73 & 89 & 91 & 90 & 87 & 75 & 83 & 81 & $* *$ & $\mathrm{NS}$ & * \\
\hline
\end{tabular}

$1 * P<0.05,{ }^{* *} P<0.01, * * * P<0.001, \mathrm{NS}:$ non significant effect $(P>0.05)$.

2DS: Dry season, IS: Intermediate season, RS: Rainy season.

${ }^{3}$ Effect of age of regrowth (AR), season $(\mathrm{S})$ or interaction $\mathrm{AR}^{*} \mathrm{~S}$.

${ }^{4}$ Milk production, means adjusted to live weight and BCS of the doe.

${ }^{5}$ Production at fixed stage $10 \mathrm{~d}-30 \mathrm{~d}$ from 10 days to 30 days of lactation, $30 \mathrm{~d}-70 \mathrm{~d}$ from 30 days to 70 days of lactation.

${ }^{6} \mathrm{ADG}$ : average daily gain, means adjusted to milk production of the mother and birth weight of the kid. 

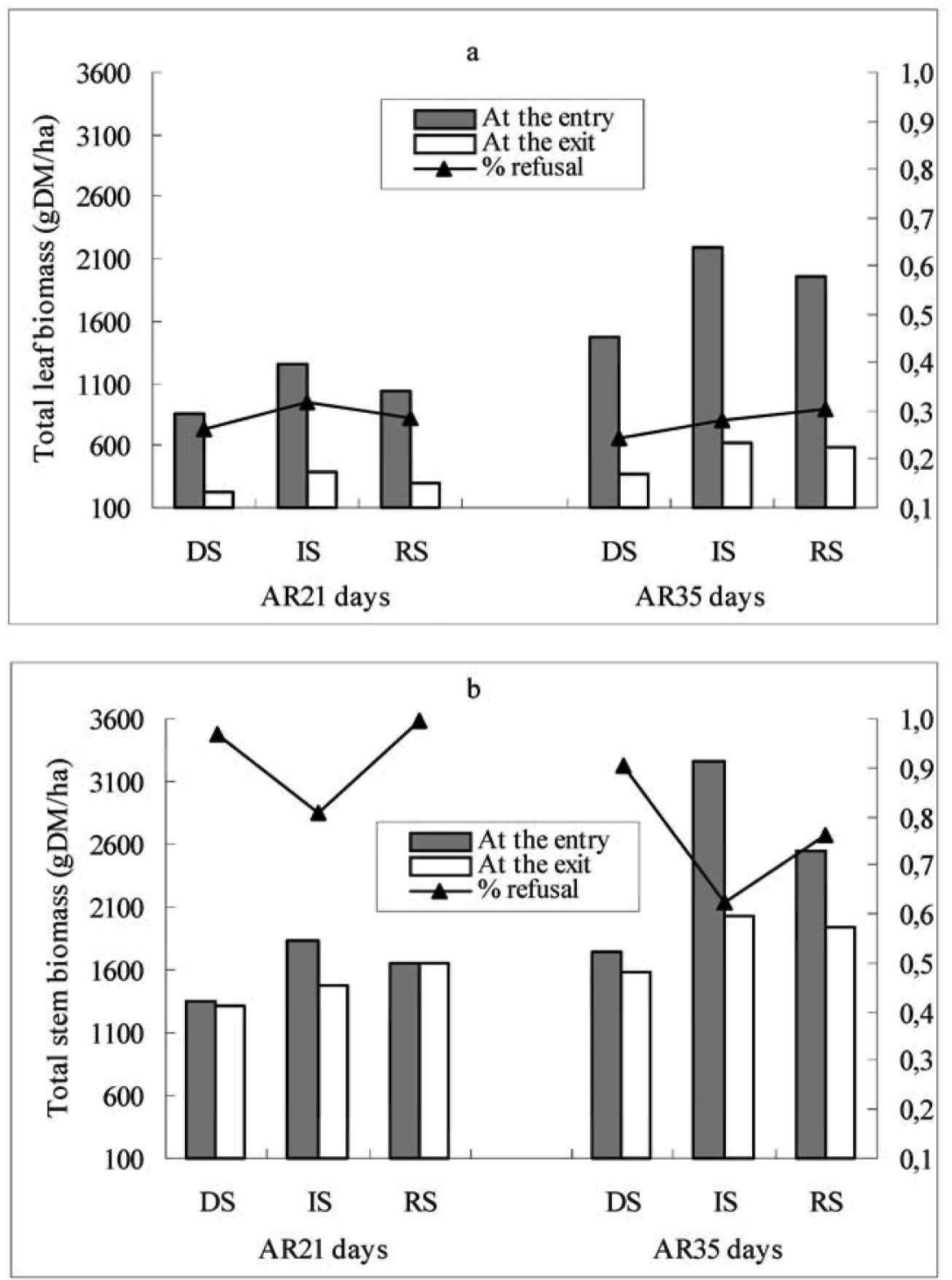

FIGURE 1. Rotational grazing systems based on irrigated Digitaria decumbens in Guadeloupe (F.W.I.) grazed by suckling Creole goats and their kids: biomass (DM kg/ha) and percentage of refusal of leaf (a) and of stem (b) at entry and exit of animals in the paddock, according to age of regrowth (AR) and season (dry DS, intermediate IS, rainy RS; defined in the text). 
the AR35 group ( $86 \mathrm{~g}$ ). Differences between AR groups of kids were substantial, a maximum of $23 \%$ during the last period of suckling from 30 to 70 days, especially during the RS and IS.

\section{DISCUSSION}

The decrease in herbage mass, induced by a lower AR and variation among the seasons, was consistent with existing knowledge on tropical C4 forage plants that are productive and season-dependent (Crespo, 1985; Humphreys, 1991). In fact, the daily herbage accumulation of approximately $140 \mathrm{DM} \mathrm{kg} / \mathrm{ha}$ was similar within AR systems. This value is very high in comparison with other reported results, perhaps because of the high level of fertilization used in the present study. Calculations taking into account the surface area and pasture biomass indicated similar weekly levels of forage on offer (about $15 \mathrm{DM} \mathrm{kg} /$ doe) for both AR systems. In addition, the leaf proportion of the forage did not vary significantly. Thus, no differences between grazing systems were recorded for sward availability and structure. Cruz et al. (1989) have shown that leaf proportion depends on the AR of the forage. However, in our experiment, this value was higher in the control system (AR35) than in the forage grazed at 21 days of age. In fact, conditions differed between the two experiments; Cruz et al. (1989) made their observations on ungrazed forage whereas in the present case many grazing cycles took place and may have influenced the physiology of the forage and sward canopy. The low leaf to stem ratios, always less than unity in the present study, have frequently been observed in many tropical grasses, as reported by Minson (1990) and Humphreys (1991). Under intensive pasture management (irrigation and fertilization), accumulation of stolons rapidly exceeds that of green leaf material and this deterioration in quality is reflected in the accumulation of materials at the end of the grazing cycle. In the present study the accumulated material was $64 \%$ stems and $21 \%$ debris on average. In experiments in which the post-grazing residues are controlled, the leaf to stem ratio is improved and can reach 1.04 (Ortega-Jimenez et al., 2006).

In contrast to results obtained with confined animals fed cut grass (Archimède et al., 2000), lowered AR in the present study did not improve sward quality and milk performance as expected. Both systems of pasture management may have provided enough forage for the breeding females since they performed similarly. The large amount of green material offered probably allowed an adequate selective grazing behaviour in both systems. This finding is consistent with the high calculated refusal rates found for all $\mathrm{AR}$ systems and seasons ( $61 \%$ of the total green material). It is frequently reported in goat nutrition literature (Morand- 
Fehr, 1991) that refusal rate and intake level are positively correlated. Masson et al. (1991) concluded that dairy goats (around $60 \mathrm{~kg} \mathrm{LW}$ ) raised under temperate conditions and offered more than $2 \mathrm{~kg}$ of DM daily can adapt to intensive grazing on artificial pastures. The lactating Creole goats (around $32 \mathrm{~kg} \mathrm{LW}$ ) used in the current study were offered 2.08 and $2.23 \mathrm{~kg} \mathrm{DM}$ daily in AR21 and AR35, respectively. Therefore, the level of forage offered was not a limiting factor in either AR treatment. The intake level was not assessed at pasture; nevertheless, the difference between the level of forage at entry and exit of the animals allowed calculations of the quantity of forage "used" in the different systems. It reached approximately $766 \mathrm{~g} \mathrm{DM}$ of total green material (leaves + stems) per doe daily. The daily total feed intake (pasture + supplement) would then be estimated at $942 \mathrm{~g} \mathrm{DM}$, which is consistent with values reported from other experiments that used lactating Creole goats under grazing (Alexandre et al., 1997; Ortega-Jimenez et al., 2005).

Furthermore, since the animals were supplemented, this additional feed would probably have compensated for slight differences in nutritive value of the forage. The does did not lose weight and their body condition remained constant. Also, milk yields of our goats (950 to $1,050 \mathrm{~g} / \mathrm{d}$ ) were higher than those reported for other tropical breeds reared on pasture in Senegal ( $873 \mathrm{~g} / \mathrm{d}$ ) (Cissé et al., 2002) or South Africa $(800 \mathrm{~g} / \mathrm{d})$ (Greyling et al., 2004), thus indicating good feeding conditions in our experiment.

The seasonal differences in herbage mass were consistent with those of other reports on the growth of Digitaria decumbens (Cruz et al., 1989; Hacker and Evans, 1992; Alexandre et al., 1997; Gargano and Adúriz, 2001). At both AR, daily DM accumulation was $63 \%$ higher during longer days in IS than during shorter days in DS (about 172 vs. 108 $\mathrm{DM} \mathrm{kg} / \mathrm{ha}$ ). The morphological composition also varied with the season as previously reported (Cruz et al., 1989; Hacker and Evans, 1992; Velasco et al., 2001).

Although the seasonal effect on milk production did not reach significance, season seemed to affect both forage availability and milk production in the same way. In IS, the differences between AR35 and AR21 were important for forage "consumption" (18\% difference) and for MP $30 \mathrm{~d}$ to $70 \mathrm{~d}$ (22\% difference). These findings agree with those reported by Ortega-Jimenez et al. (2005) for Creole goats on pasture.

The present ADG values obtained from birth to weaning ( 75 to $86 \mathrm{~g}$ ) were at the lower end of the range of variation reported by OrtegaJimenez et al. (2003) for Creole goat twins (65 to $108 \mathrm{~g}$ ). Daily weight gain adjusted for birth weight and dam's MP provided further evidence that kids grow better under the AR35 system than under the AR21. The relatively low ADG level indicates that husbandry conditions were 
somewhat limiting. Assuming that herbage allowances and feeding conditions were at a satisfactory level in both AR systems, another source of variation must have been involved. During the first stage of growth $10 \mathrm{~d}$ to $30 \mathrm{~d}$, kids depend mainly on maternal milk production to ensure normal growth, as reported by Alexandre et al. (1999). During the last period of suckling ( 30 to 70 days of age) differences between AR groups in daily gain were more pronounced ( $23 \%$ difference), thus suggesting a possible negative effect of gastro-intestinal parasitism (Aumont et al., 1997), even though monthly anthelmintic drenches were administered. An AR lower than 28 days has been found to dramatically increase infestation risk in rotational grazing systems under intensive conditions (Aumont et al., 1991). The nematode parasite populations grow rapidly during the first three weeks from the end of the grazing in a paddock until the return of animals to the same paddock at the start of the next grazing cycle.

\section{CONCLUSION}

Improvement of the canopy structure of Digitaria decumbens is difficult to achieve through regulation of $\mathrm{AR}$ under fixed grazing management conditions. The biology of stoloniferous $\mathrm{C} 4$ tropical grasses makes it difficult to manage them so as to provide the type of leafy sward necessary for high-yielding livestock. In this experiment forage supply was in excess. Further studies are required to develop grazing and animal management practices effective in reducing input while maintaining high animal output. The irrigation and fertilizer management regime should be changed to reduce the excess biomass obtained from these high yielding pastures and thus prevent the large volume of refusals. Future studies are needed on the changes in nutritive value of the sward over time and the determination of voluntary intake of herbage during grazing.

Moreover, effects of gastro-intestinal parasitism must be taken into account in these studies. For reasons relating to infestation risk, it is highly recommended that the stocking rate not be increased in order to make use of the available forage mass; at the same time, pasture should not be grazed if AR is less than 21 days. A balance must be sought that allows optimum small ruminant output from tropical pastures.

\section{LITERATURE CITED}

Alexandre, G., 1983. Production laitière des chèvres Créoles. Facteurs de variation et influence sur la croissance des jeunes. pp 138. Thèse de docteur ingénieur, ENSA Rennes. 
Alexandre, G., G. Aumont, J. Fleury, O. Coppry, P. Mulciba and A. Nepos, 1997. Production semi intensive au pâturage de caprins à viande en zone tropicale humide: le cas des cabris Créoles sur Pangola (Digitaria decumbens) en Guadeloupe. INRA, Prod Anim. 10:43-54.

Alexandre, G., G. Aumont, J. C. Mainaud, J. Fleury and M. Naves, 1999. Productive performances of Guadeloupean Creole goats during the suckling period. Small Rumin. Res. 34:157-162.

Archimède, H., M. Boval, G. Alexandre, A. Xandé, G. Aumont and C. Poncet, 2000. Effect of regrowth age on intake and digestion of Digitaria decumbens consumed by Black-belly sheep. Anim. Feed Sci. Technol. 87:153-162.

Aumont, G., I. Caudron, G. Saminadin and A. Xandé, 1995. Sources of variation in nutritive values of tropical forages from the Caribbean. Anim. Feed Sci. Technol. 51:1-13.

Aumont, G., L. Gruner and P. Berbigier, 1991. Dynamique des populations de larves infestantes des strongles gastro-intestinaux des petits ruminants en milieu tropical humide. Conséquences sur la gestion des pâturages. Rev. Elev. Med. Vét. pays Trop. spécial issue: 123-131.

Aumont, G., F. Poisot, G. Saminadin, H. Borel and G. Alexandre, 1994. Body condition score and adipose cell size determination for in vivo assessment of body composition of creole goats. Small Rumin. Res. 15:77-86

Aumont, G., R. Pouillot, R. Simon, G. Hostache, N. Barré and H. Varo, 1997. Parasitisme digestif des petits ruminants dans les Antilles françaises. INRA Prod.Anim. 10:79-90.

Aumont G., A. Xandé and J. Bellanger, 1996. Macro-minerals and trace elements contents of pangola grass and other forages in Guadeloupe (F.W.I.). J. Agric. Uniw. P. R. $80: 21-35$.

Baumont, R., S. Prache, M. Meuret and P. Morand-Fehr, 2000. How forage characteristics influence behaviour and intake in small ruminants: A review. Cah. Options Méditerr. 52:11-25.

Cissé, M., I. Ly, A. J. Nianogo, I. Sané and J. G. Sawadogo, 2002. Grazing behaviour and milk yield of Senegalese Sahel Goat. Small Rumin. Res. 43:85-95.

Crespo, G., 1985. Variation in the response of tropical pastures to nitrogenous fertilizers throughout the year. 2. Pangola (Digitaria decumbens Stent) grass with irrigation. Cuban J. Agric. Sci. 19:307-32.

Cruz, P., G. Alexandre and H. Baudot, 1989. Cinétique de la croissance foliaire et stolonifere d'un peuplement de Digitaria decumbens au cours de la repousse. Proceedings of the XVI International Grassland Congress, Nice, France 1: 499-500.

Devendra, C. and M. Burns, 1983. Goat production in the Tropies. Commonwealth Agricultural Bureaux. 193 pp.

Gargano, A. O. and M. A. Adúriz, 2001. Diferencias estacionales en rendimiento y calidad de Digitaria eriantha ev. Irene. Mem. XVII Reunión Asoc. Latinoam. Prod. Anim. La Habana, Cuba. pp. 100-103.

Greyling, J. P. C., V. M. Mmbengwa, L. M. J. Schwalbach and T. Muller, 2004. Comparative milk production potential of indigenous and Boer goats under two feeding systems in South Africa. Small Rumin. Res. 55:97-105.

Hacker, J. B. and T. R. Evans, 1992. An evaluation of the production potential of six tropical grasses under grazing. 1. Yield and yield components, growth rates and phenology. Aust. J. Exp. Agric. 32:19-27.

Humphreys, L. R., 1991. Tropical pasture utilization. $1^{\text {st }}$ ed. Cambridge University, Great Britain. 206 pp.

Masson, C., R. Rubino and V. Fedele, 1991. Forage utilization in goats. In: P. MorandFehr (ed.), Goat nutrition. Pudoc, Wageningen, Netherlands. pp. 145-159.

Minson, D. J., 1990. Forage in ruminant nutrition. Academic Press, Inc., New York. 483 pp. 
Morand-Fehr, P., 1991. Goat nutrition. Pudoc, Wageningen, Netherlands. 308 pp.

Ortega-Jimenez, E., G. Alexandre, R. Arquet, O. Coppry, M. Mahieu and A. Xandé, 2003. Consequences of post-grazing residues control and birth season on the body traits, reproductive performance and offspring's growth of suckling goats and ewes reared at pasture in Guadeloupe (FWI). Asian Australasian J. Anim Sci. 16:1108-1117.

Ortega-Jimenez, E., G. Alexandre, M. Boval, H. Archimède, M. Mahieu and A. Xandé, 2005. Intake and milk production of suckling Creole goats reared at pasture in humid tropics according to the post-grazing residue management. Small Rumin. Res. 59: 217-227.

Ortega-Jimenez E., G. Alexandre, O. Coppry, G. Saminadin, P. Cruz and A. Xandé, 2006. Post-grazing residue control, season and forage characteristics of tropical pastures grazed by goats and ewes in Guadeloupe (FWI.). J. Agric. Univ. P.R. 90:37-56.

SAS, 1989. Statistical Analysis Systems User's Guide (6th ed.). SAS Institute Ine., Cary, North Carolina. 151 pp.

Velasco, Z. Ma. E., A. Hernández-Garay, V. A. González-Hernández, P. J. Pérez and H. Vaquera, 2001. Dinámica de crecimiento, rendimiento y calidad de forraje de Dactylis glomerata L. en respuesta a la defoliación. Mem. XVII Reunión Asoc. Latinoam. Prod. Anim. La Habana, Cuba. pp. 77-79. 